\title{
Analisis Efisiensi Ekonomi Penggunaan Faktor Produksi Usahatani Padi Sawah Organik di Desa Pasar Terusan Kecamatan Muara Bulian Kabupaten Batanghari
}

\author{
Viona Febrina $^{1)}$, Dewi Sri Nurachaini ${ }^{2)}$, dan Ardhyan Saputra ${ }^{2)}$ \\ 1) Alumni Program Studi Agribisnis Fakultas Pertanian Universitas Jambi \\ 2) Staf Pengajar Program Studi Agribisnis Fakultas Pertanian \\ Universitas Jambi \\ Email : Viona.febrina@gmail.com
}

\begin{abstract}
ABSTRAK
Penlitian ini dilaksanakan bertujuan untuk (1) Mengetahui gambaran kegiatan usahatani padi sawah organik di daerah penelitian (2) Mengetahui pengaruh faktor-faktor produksi usahatani padi sawah organik terhadap produksinya (3) Mengetahui tingkat efisiensi ekonomi penggunaan faktor produksi pada produksi padi sawah organik. Ukuran Sampel yang digunakan dalam penelitian ini sebanyak 45 petani, penarikan sampel dilakukan dengan metode acak sederhana. Alat analisis yang digunakan pada penelitian ini adalah analisis regresi berganda dengan pendekatan fungsi produksi Cobb Douglass.

Hasil penelitian menunjukkan bahwa secara parsial pengaruh faktor-faktor produksi padi sawah organik yang berpengaruh nyata terhadap produksi padi sawah organik adalah luas lahan, benih, pupuk organik, dan tenaga kerja sedangkan obat-obatan tidak berpengaruh nyata terhadap produksi padi sawah organik. Tingkat Efisiensi ekonomi penggunaan faktor produksi yang memiliki indeks efisiensi ekonomi $>1$ adalah luas lahan, benih, artinya faktor produksi tersebut perlu ditambah penggunaanya untuk menambah hasil produksi padi sawah organik, dan faktor produksi benih mencapai efisiensi ekonomi tertinggi sedangkan indeks efisiensi ekonomi < 1 yaitu tenaga kerja yang artinya faktor produksi tersebut perlu dikurangi penggunaanya untuk mendapatkan produksi yang optimal.
\end{abstract}

Kata Kunci: Efisiensi, Faktor Produksi, Fungsi Produksi, Padi Organik.

\section{ABSTRACT}

This research aims to (1) Knowing Knowing picture organic paddy farming activities in the area of research (2) Knowing the influence of factors of production of organic paddy rice farming to production (3) Knowing the level of economic efficiency in the use of production factors and organic rice production. The research was conducted in August until the month of September 2015. he sample size used in this study were 45 farmers, Sampling is done by simple random method. The analytical tool used in this study is multiple regression analysis with Cobb Douglass production function approach.

The results showed that the partial influence of factors of organic rice production significantly affect rice production is organic land, seeds, organic fertilizer, and labor while the drugs did not significantly affect rice production of organic. The level of economic efficiency of use of production factors that have an index of economic efficiency> 1 is the area of land, seeds and organic fertilizers means of production factors is necessary plus its use to add to the rice production of organic and factors of production of seed reaching economic efficiency high while the index of economic efficiency $<1$ ie drugs and labor, which means that production factors need to be reduced their use to obtain optimal production.

Keywords: efficiency, Factors of Production, Production Function, Organic Rice. 


\section{PENDAHULUAN}

Pertanian organik telah disosialisasikan di Indonesia sejak Tahun 2001, dan salah satu kebijakan pemerintah dalam mempertahankan dan meningkatkan produktivitas tanaman pangan termasuk padi adalah dengan menerapkan pertanian tanaman pangan organik atau yang lebih sering disebut pertanian tanaman pangan berkelanjutan. Sumber daya alam yang dimiliki oleh negara kita, Indonesia berpeluang besar menjadi produsen pangan organik. Indonesia memiliki lahan pertanian tropik dengan plasma nutfah yang sangat beragam, dan ketersediaan bahan organik yang berlimpah. Dengan adanya program pemerintah Go Organik 2010 yang memiliki aspek peningkatan mutu, nilai tambah, efisiensi sistem produksi, serta kelestarian sumberdaya alam, dan lingkungan yang merupakan isu dan menjadi sasaran utama. Hal yang juga sangat penting dari program ini adalah peningkatan pendapatan petani dan pelestarian sumberdaya alam dan lingkungan (Deptan, 2007). Dalam mewujudkan program Go Organik 2010, pemerintah mendukung pengembangan pertanian organik dengan adanya kebijakan peningkatan produksi pertanian organik dengan sasaran produksi pertanian organik pada komoditi padi pada Tahun 2009 sebesar 562.000 Ton.

Tujuan dari penerapan usahatani padi organik adalah sebagai bentuk cara peningkatan produksi padi. Dalam penelitian ini, usahatani padi organik melakukan cara penanaman, penggunaan input dan memperoleh hasil produksi, selain mengenai peningkatan produksi padi organik serta mepertahankan unsur hara dalam tanah, biaya yang dikeluarkan tentunya juga memperngaruhi petani dalam berusahatani padi. Salah satu upaya untuk mengatasi rendahnya produksi pertanian non organik adalah dengan mengubah menjadi pertanian organik. Pertanian organik menggunakan sarana produksi seperti benih yang digunakan sedikit, pupuk organik, dan pestisida organik. Pertanian organik ini membuat petani menjadi mandiri karena dapat membuat sarana produksi sendiri dengan menggunakan bahan-bahan organik yang mudah didapat seperti kotoran ternak dan limbah pertanian sebagai pupuk, serta tumbuh-tumbuhan sekitar sebagai pestisida nabati. Akibatnya pertanian organik juga dapat menekan biaya produksi.

Dalam meningkatkan produksi padi, adanya penerapan pertanian organik melalui usahatani padi organik diharapkan dapat meningkatkan produksi padi. Selain meningkatkan produksi padi, usahatani padi organik ini juga dapat memperbaiki kondisi tanah dengan penggunaan pupuk organik dalam budidayanya. Respon jumlah produksi terhadap perubahan jumlah faktor produksi menjadi indikator efisiensi usahatani. Tingkat penggunaan input yang rendah dan belum optimal akan menyebabkan rendahnya tingkat produksi, sehingga tingkat efisiensi usahatani padi organik diduga pula masih rendah. Peningkatan efisiensi usahatani padi organik terus digalakkan oleh petani dan pemerintah, sehingga perlu dikaji bagaimana pengaruh penggunaan faktor-faktor produksi dan efisiensi ekonomis usahatani padi organik. Pengukuran efisiensi dan produktivitas serta aktivitas ekonomi sangatlah penting sebagai tolak ukur antara selisih input yang digunakan dengan output yang dihasilkan. Berdasarkan uraian diatas, permasalahan yang menjadi permasalahan dalam penelitian ini adalah (1) Bagaimana gambaran kegiatan usahatani padi organik di desa Pasar Terusan kecamatan Muara Bulian Kabupaten Batanghari (2) Bagaimana pengaruh faktor-faktor produksi usahatani padi organik terhadap produksinya di desa Pasar Terusan kecamatan Muara Bulian Kabupaten Batanghari (3) Bagaimana tingkat efisiensi ekonomi penggunaan faktor produksi terhadap produksi padi organik di desa Pasar Terusan kecamatan Muara Bulian Kabupaten Batanghari (4) Bagaimana kelayakan usaha atau R C rasio pada usahatani padi sawah organik di desa Pasar Terusan Kecamatan Muara Bulian Kabupaten Batanghari.

\section{METODE PENELITIAN}

Penelitian ini dilaksanakan di Desa Pasar Terusan Kecamatan Muara Bulian Kabupaten Batanghari. Penelitian ini dilaksanakan pada tanggal 29 Agustus sampai dengan tanggal 29 September. Lokasi penelitian ini dipilih dengan pertimbangan merupakan daerah sentra produksi padi organik. Objek pada penelitian ini terdiri dari 3 kelompok tani yang ada di desa Pasar Terusan. 
Data yang dikumpulkan meliputi data primer dan data sekunder. Data primer dikumpulkan dari petani padi organik. Sedangkan data sekunder dikumpulkan dari laporan hasil penelitian, instansi terkait, dan literatur-literatur yang digunakan dalam penelitian ini. Penelitian dilakukan secara purposive yaitu di Desa Pasar Terusan Kecamatan Muara Bulian. Desa Pasar Terusan dipilih dengan pertimbangan bahwa Desa tersebut merupakan desa yang mengusahakan padi organik dan memiliki lahan yang cukup luas. Penarikan sampel responden didasarkan pada penarikan penarikan sampel minimal 5 persen, hal ini sesuai dengan pendapat Singarimbun (1995), yang menyatakan bahwa dalam suatu penelitian yang menggunakan metode survey tidaklah perlu untuk meneliti populasi secara keseluruhan, karena selain membutuhkan biaya yang cukup besar juga membutuhkan waktu yang lama dan makin seragam populasi, maka makin kecil sampel yang diambil. Diketahui bahwa jumlah petani padi organik adalah 445 petani yang terdiri dari 3 kelompok tani. Untuk kelompok tani Payo Kering I berjumlah 87 diambil 10\% sehingga di dapat sampel 9 petani, untuk kelompok tani Payo Kering II berjumlah 183 petani diambil 10\% didapat sampel 18 petani, dan untuk kelompok tani Sumber Rezeki berjumlah 175 petani diambil 10\% didapat sampel sebesar 18 petani. Sehingga jumlah sampel petani adalah sebanyak 45 petani. Analisis regresi digunakan untuk memprediksi hubungan sebab akibat antara variabel independen dengan variabel menggunakan Model fungsi produksi Cobb-Douglas

$$
\mathrm{Y}=\mathrm{A} \prod_{i}^{n} X i^{\mathrm{Bi}}
$$

Dalam penelitian ini model ditransformasikan menjadi:

$\log Y=A+\beta_{1} \log X_{1}+\beta_{2} \log X_{2}+\beta_{3} \log X_{3}+\beta_{4} \log X_{4}+\beta_{5} \log X_{5}$

Keterangan:

$\mathrm{Y} \quad=$ Jumlah total produksi padi ( $\mathrm{kg})$

$\mathrm{X}_{1} \quad=$ Luas lahan usahatani padi organik (ha)

$\mathrm{X}_{2} \quad=$ Jumlah benih padi $(\mathrm{kg})$

$X_{3} \quad=$ Pupuk Organik $(\mathrm{kg})$

$\mathrm{X}_{4} \quad$ = Penggunaan obat-obatan (liter)

$\mathrm{X}_{5} \quad=$ Tenaga Kerja (HOK)

$\mathrm{A}=$ Konstanta

$\beta_{\mathrm{i}}=$ Koefisien Regresi; $i=1,2,3, \ldots .5$

$\alpha_{i}=$ Koefisien Regresi; $i=1,2,3, \ldots .5$

$\mu=$ Kesalahan Pengganggu

Untuk menguji apakah variabel-variabel bebas secara bersama-sama berpengaruh terhadap variabel terikat digunakan uji bersama atau uji $\mathrm{F}$ dengan menghitung terlebih dahulu besarnya variabel tidak bebas (dependent variabel) yang dapat diterangkan oleh variabel bebas (independent variabel) yang dapat dihitung dengan menggunakan koefisien determinasi $\left(R^{2}\right)$ (Gujarati, 2003), yaitu sebagai berikut :

$R^{2}=\frac{b_{i} \sum x i y i}{\sum y i^{2}}$

Uji F dengan hipotesis sebagai berikut:

1. $H o: R^{2}=0$

$\mathrm{Ha}: \mathrm{R}^{2} \neq 0$

2. Kriteria pengambilan keputusan :

a. $\quad F_{\text {hitung }} \geq F_{\text {Tabel }}$ maka Ho ditolak atau Ha diterima artinya secara bersama-sama variabel bebas berpengaruh nyata terhadap variabel terikat

b. $F_{\text {hitung }} \leq \mathrm{F}_{\text {Tabel }}$ maka Ho diterima atau Ha ditolak artinya secara bersama-sama variabel bebas tidak berpengaruh nyata terhadap variabel terikat.

Nilai $F_{\text {hitung }}$ dicari dengan rumus berikut:

$F_{\text {hit }}=\frac{R^{2} /(k-1)}{\left(1-R^{2}\right) /(n-k)}$

Dimana :

$\mathrm{R}^{2}=$ Koefisien determinasi (goodness of fit)

$\mathrm{k}=$ Jumlah variabel independent atau derajat bebas $(\mathrm{db})$ regresi 
$\mathrm{n}$ = Jumlah sampel penelitian

Selanjutnya untuk menguji pengaruh masing-masing variabel bebas terhadap variabel terikat digunakan uji t (t-test) dengan hipotesis sebagai berikut:

1. $H o: \beta_{i}=0$

$\mathrm{Ha}: \beta_{\mathrm{i}} \neq 0$

2. Kriteria pengambilan keputusan:

a. Jika $t_{\text {hit }} \geq t_{\text {Tabel }}(\alpha=5 \% d b=n-1)$ maka tolak Ho atau terima Ha artinya secara parsial variabel bebas berpengaruh nyata terhadap variabel terikat.

b. Jika $t_{\text {hit }} \leq t_{\text {Tabel }}(\alpha=5 \% d b=n-1)$ maka terima Ho atau tolak Ha artinya secara parsial variabel bebas tidak berpengaruh nyata terhadap variabel terikat.

Nilai $t_{\text {hitung }}$ dicari dengan rumus berikut:

$t_{\text {hit }}=\frac{b i}{S b i}$

Dimana :

$\mathrm{T}_{\text {hit }} \quad=$ Nilai t hitung

$b_{i} \quad=$ Koefisien regresi perkiraan ke- $b_{i}$

$\mathrm{Sb}_{\mathrm{i}} \quad=$ Standar eror perkiraan ke- $b_{\mathrm{i}}$

$\mathrm{i} \quad=1,2,3,4$, dan 5

Menurut Soekartawi (1994), pengujian tingkat efisiensi ekonomis penggunaan faktor produksi dilakukan dengan membandingkan nilai produk marginal (NPM) dengan harga faktor produksi ( $\mathrm{Hx}$ ), yakni dengan kaidah sebagai berikut :

$\frac{N P M x i}{H x i}<1$ Artinya : Penggunan faktor produksi ke-1 tidak efisien, untuk mencapai efisien maka faktor produksi perlu dikurangi.

$\frac{N P M x i}{H x i}=1$ Artinya $\quad$ : Penggunaan Input sudah efisien

$\frac{N P M x i}{H x i}>1$ Artinya $\quad$ : Penggunaan faktor produksi ke-i belum efisien, untuk mencapai efisien maka faktor produksi perlu ditambah.

Analisis ini digunakan untuk mengetahui berapa besar penerimaan yang diterima untuk setiap rupiah yang dikeluarkan untuk memproduksi. Formula yang digunakan untuk menghitung $\mathrm{R} \mathrm{C}$ rasio adalah sebagai berikut :

$$
\mathrm{R} C=\frac{\text { Penerimaan }(R)}{\text { Total Biaya }(C)} \text {. }
$$

Keterangan :

R C $>1$, Artinya Usahatani memberikan manfaat dan layak untuk dilanjutkan.

R C <1, Artinya Usahatani tidak memberikan manfaat bahkan merugikan atau tidak layak untuk dilanjutkan.

$\mathrm{RC}=1$, Artinya Usahatani tidak memberikan manfaat atau menguntungkan dan tidak layak untuk dilanjutkan.

\section{HASIL DAN PEMBAHASAN}

\section{Identitas Petani \\ Umur Petani}

Umur akan mempengaruhi kemampuan fisik petani dalam bekerja dan kemampuan dalam berpikir. Semakin tua umur petani maka kemampuan fisiknya dalam bekerja akan semakin menurun. Menurut soekartawi (1988) menyatakan bahwa semakin muda umur seseorang biasanya memiliki semangat untuk ingin tahu tentang hal - hal yang belum petani ketahui, sehingga akan berusaha lebih cepat dalam melakukan adopsi inovasi walaupun masih belum berpengalaman dalam adopsi inovasi tersebut. Untuk lebih jelas tentang distribusi petani berdasarkan umur di daerah penelitian dapat di lihat pada Tabel 1. 
Tabel 1. Distribusi Frekuensi Dan Persentase Petani Sampel Berdasarkan Umur Di Daerah Penelitian Tahun 2015.

\begin{tabular}{ccc}
\hline Kelompok Umur (Tahun) & \multicolumn{2}{c}{ Jumlah Petani } \\
\cline { 2 - 3 } & (KK) & (\%) \\
\hline $30-36$ & 4 & 8,90 \\
$37-43$ & 6 & 13,32 \\
$44-50$ & 23 & 51,06 \\
$51-57$ & 5 & 11,11 \\
$58-64$ & 4 & 8,90 \\
$65-71$ & 3 & 6,66 \\
\hline Total & $\mathbf{4 5}$ & $\mathbf{1 0 0}$ \\
\hline
\end{tabular}

Petani dalam usia produktif keadaan fisiknya diharapkan mampu untuk menerapkan teknologi usahatani padi sawah organik. Begitu pula dalam pengambilan keputusan seperti halnya mempertimbangkan masuknya teknik baru, termasuk didalamnya teknologi baru untuk budidaya padi sawah organik. Petani hendaknya dapat dengan cepat mengambil keputusan melalui bantuan pemikiran, penerangan dan kegiatan penyuluhan pertanian.

\section{Tingkat Pendidikan Petani}

Distribusi frekuensi dan persentase petani sampel berdasarkan tingkat pendidikan formal di daerah penelitian dapat dilihat pada Tabel 2:

Tabel 2. Distribusi Petani Sampel Berdasarkan Tingkat Pendidikan Formal Di Daerah Penelitian Tahun 2015.

\begin{tabular}{lcc}
\hline \multirow{2}{*}{ Tingkat Pendidikan } & \multicolumn{2}{c}{ Jumlah Petani } \\
\cline { 2 - 3 } & (KK) & (\%) \\
\hline Tingkat SD/Sederajat & 23 & 51,11 \\
Tingkat SMP/Sederajat & 16 & 35,56 \\
Tingkat SMA/Sederajat & 6 & 13,33 \\
\hline \multicolumn{1}{c}{ Total } & $\mathbf{4 5}$ & $\mathbf{1 0 0}$ \\
\hline
\end{tabular}

Tabel 2 memperlihatkan bahwa pada umumnya petani sampel di daerah penelitian yang paling dominan mengenyam pendidikan tingkat SD/Sederajat yaitu sebanyak 33 orang dengan jumlah persentase sebesar 39,29 \%. Hal ini sejalan dengan pendapat Soekartawi (1988) mengemukakan bahwa petani yang berpendidikan tinggi adalah relatif lebih cepat dalam melaksanakan adopsi inovasi. Begitu pula sebaliknya petani yang berpendidikan rendah agak sulit untuk melaksanakan adopsi inovasi dengan cepat.

\section{Jumlah Anggota Keluarga}

Jumlah anggota petani padi sawah organik didaerah penelitian cukup bervariasi namun sebagian besar petani hanya memiliki jumlah anggota keluarga sebanyak 5 sampai 6 orang dimana dapat dilihat pada Tabel 3. 
Tabel 3. Distribusi Petani Sampel Berdasarkan Jumlah Anggota Keluarga Didaerah Penelitian Tahun 2015.

\begin{tabular}{ccc}
\hline \multirow{2}{*}{ Jumlah Anggota Keluarga } & \multicolumn{2}{c}{ Jumlah Petani } \\
\cline { 2 - 3 } & (KK) & (\%) \\
\hline $1-2$ & 3 & 6,67 \\
$3-4$ & 15 & 33,33 \\
$5-6$ & 25 & 55,56 \\
$7-8$ & 2 & 4,44 \\
\hline Total & $\mathbf{4 5}$ & $\mathbf{1 0 0}$ \\
\hline
\end{tabular}

Tabel 3 menunjukkan jumlah anggota keluarga petani padi sawah organik di daerah penelitian terbanyak adalah sejumlah 5 sampai 6 orang yaitu sebanyak 25 orang $55,56 \%$. Besarnya jumlah anggota keluarga disamping dapat mendorong petani untuk bekerja lebih giat dan juga untuk mengurangi upah tenaga kerja dari luar anggota keluarga yaitu dengan menggunakan tenaga kerja keluarga itu sendiri.

\section{Pengalaman Usahatani Petani Sampel}

Pengalaman berusahatani merupakan faktor utama yang mempengaruhi keputusan petani dalam menerima teknologi baru. Adapun distribusi pengalaman berusahatani petani dapat dilihat Tabel 4.

Tabel 4. Distribusi Frekuensi Pengalaman Usahatani Petani Sampel di Daerah Penelitian Musim Tanam Tahun 2014

\begin{tabular}{ccc}
\hline Selang Kelas Pengalaman & \multicolumn{2}{c}{ Jumlah Petani } \\
\cline { 2 - 3 } (Tahun) & (KK) & (\%) \\
\hline $10-16$ & 7 & 15,5 \\
$17-23$ & 20 & 44,5 \\
$24-30$ & 10 & 22,2 \\
$31-37$ & 3 & 6,6 \\
$38-44$ & 2 & 4,5 \\
$45-51$ & 3 & 6,6 \\
\hline Total & $\mathbf{4 5}$ & $\mathbf{1 0 0}$ \\
\hline
\end{tabular}

Tabel 4 menunjukkan bahwa adanya keragaman pengalaman berusahatani dari petani sampel, pengalaman berusahatani terbesar didaerah penelitian berkisar antara 17 - 23 tahun dengan jumlah petani 20 orang dan dengan persentase $44,5 \%$. Keadaan petani padi sawah organik di daerah penelitian tersebut dapat dikatakan cukup memiliki pengalaman dalam berusahatani padi sawah organik, sehingga diharapkan petani menjadi lebih terampil dalam proses pengambilan keputusan dan pengelolaan usahatani padi sawah organik.

\section{Penggunaan Faktor Produksi Pada Usahatani Padi Sawah Organik}

Alokasi penggunaan faktor - faktor produksi merupakan kunci utama dalam mencapai produksi yang tinggi dari suatu usahatani. Secara umum input yang digunakan diantaranya adalah lahan, benih, pupuk, obat-obatan dan tenaga kerja. Penggunaan faktor-faktor produksi tersebut dapat dilihat pada Tabel 5 : 
Tabel 5. Rata-rata Penggunaan Faktor Produksi Usahatani Padi Sawah Organik di Daerah Penelitian Tahun 2014

\begin{tabular}{llc}
\hline No & \multicolumn{1}{c}{ Faktor Produksi } & Rata-rata \\
\hline $\mathbf{1}$ & Produksi $(\mathrm{Y})$ & 4674,89 \\
$\mathbf{2}$ & Luas Lahan $\left(\mathrm{X}_{1}\right)(\mathrm{Ha})$ & 0,78 \\
$\mathbf{3}$ & Benih $\left(\mathrm{X}_{2}\right)(\mathrm{Kg})$ & 18,71 \\
$\mathbf{4}$ & Pupuk Organik $\left(\mathrm{X}_{3}\right)(\mathrm{Kg})$ & $1.079,11$ \\
$\mathbf{5}$ & Obat-obatan $\left(\mathrm{X}_{4}\right)(\mathrm{Ltr})$ & 1,94 \\
$\mathbf{6}$ & Tenaga Kerja $\left(\mathrm{X}_{5}\right)(\mathrm{HOK})$ & 77,03 \\
\hline
\end{tabular}

Dari Tabel 5 diatas terlihat bahwa petani sampel di daerah penelitian ini memiliki dan menggunakan faktor produksi tersebut pada kegiatan usahatani padi sawah organik. Penggunaan secara efisien faktor produksi pada usahatani padi sawah organik di daerah penelitian ini perlu diterapkan untuk meningkatkan produksi padi sawah organik.

\section{Analisis Fungsi Produksi}

Hasil analisis penggunaan faktor produksi dilakukan melalui pendekatan fungsi CobbDouglass, dimana variabel dependent $(\mathrm{Y})$ adalah produksi padi sawah organik dan independent $(\mathrm{X})$ adalah faktor produksi yang digunakan pada usahatani padi sawah organik. Variable $X$ terdiri dari: lahan $\left(X_{1}\right)$, benih $\left(X_{2}\right)$, pupuk $\left(X_{3}\right)$, obat-obatan $\left(X_{4}\right)$, dan tenaga kerja $\left(X_{5}\right)$. Untuk mengetahui estimasi parameter fungsi produksi padi sawah organik di daerah penelitian tahun 2014 dapat dilihat pada Tabel 6 berikut:

Tabel 6. Pengaruh Faktor-Faktor Produksi Pada Usahatani Padi Sawah Organik pada Musim Tanam 2014.

\begin{tabular}{crrrr}
\hline \hline \multicolumn{1}{c}{ Variable } & Coefficient & Std. Error & t-Statistic & Prob. \\
\hline \hline LGX1 & 0.624424 & 0.085668 & 7.288846 & 0.0000 \\
LGX2 & 0.293736 & 0.074828 & 3.925482 & 0.0003 \\
LGX3 & 0.041139 & 0.031086 & 1.323404 & 0.1934 \\
LGX4 & -0.048475 & 0.059497 & -0.814744 & 0.4202 \\
LGX5 & 0.078964 & 0.038804 & 2.034935 & 0.0487 \\
C & 7.132153 & 0.320243 & 22.27103 & 0.0000 \\
\hline \hline R-squared & 0.996203 & Mean dependent var & 8.392378 \\
Adjusted R-squared & 0.995716 & S.D. dependent var & 0.320314 \\
S.E. of regression & 0.020965 & Akaike info criterion & -4.768317 \\
Sum squared resid & 0.017142 & Schwarz criterion & -4.527429 \\
Log likelihood & 113.2871 & Hannan-Quinn criter. & -4.678516 \\
F-statistic & 2046.322 & Durbin-Watson stat & 2.291021 \\
Prob(F-statistic) & 0.000000 & & \\
\hline \hline
\end{tabular}

Dari Tabel 6 di atas menunjukkan bahwa hasil analisis sidik ragam diperoleh $\mathrm{F}_{\text {hitung }}$ sebesar 2046,32 dan $F_{\text {Tabel }}$ Sebesar 2,46 pada taraf 99 \% (Prob F- Static 0,0000). Hal ini berarti model penduga digunakan memiliki akurasi (kehandalan yang sangat nyata). Model hasil pendugaan jika dipergunakan untuk melakukan pendugaan pengaruh luas lahan, benih, pupuk, obat-obatan dan tenaga kerja akan dapat menjelaskan secara nyata terhadap variasi tinggi rendahnya produksi padi sawah organik. Model juga menunjukkan tidak terdapat multikorelitas diantara variabel yang ditunjukkan oleh $\alpha=1 \%$ lebih kecil dari besarnya nilai Durbin-Watson Stat yang nilainya 2,196. 
Tabel 6 juga menunjukkan bahwa besarnya koefisien determinasi R-Sqaured $=0,9962$ dan Adjusted R-Sqaured 0,9957. Koefisien determinasi yang digunakan dalam hal ini adalah adjusted $\mathrm{R}^{2}$ karena mengingat fungsi produksi yang digunakan fungsi cobb-douglass dan viariabel-variabelnya memiliki satuan yang berbeda-beda dalam hal ini besarnya Adjusted R-Sqaure $=0,9957$ hal ini berarti besarnya variasi produksi padi sawah organik dapat dijelaskan sebesar 99,57\% oleh penggunaan secara bersama-sama faktor produksi (luas lahan, benih, pupuk, obat-obatan dan tenaga kerja). Sedangkan sisanya sebesar $0,4 \%$ dipengaruhi oleh faktor lain yang tidak termasuk kedalam model penduga. Model penduga yang digunakan. Adapun model regresi Cobb Douglass hasil pendugaan dapat diteruskan kedalam bentuk persamaan berikut :

$\mathrm{Y}=7,132 \mathrm{X}_{1}^{0,624} \cdot \mathrm{X}_{2}^{0,293} \cdot \mathrm{X}_{3}{ }^{0,041} \cdot \mathrm{X}_{4}{ }^{-0,0484} \cdot \mathrm{X}_{5}^{0,078}$

Dalam persamaan ini dapat dihitung bahwa besarnya $\sum \mathrm{bi}=0,98<1$. Hal ini berarti skala produksi berada pada Increasing Return To Scale (IRRS dalam kurva fungsi produksi) dengan kata lain setiap penambahan input sebesar $10 \%$ akan meningkatkan produksi sebesar $9,8 \%$ hal ini menandakan rasional atau efisien secara ekonomi.

Pengaruh Secara Parsial Faktor Produksi.

Luas lahan padi sawah organik yang dikuasai petani akan sangat menentukan besar produksi yang diperoleh dari usahatani. Dari hasil pendugaan regresi berdasarkan fungsi produksi Cobb Douglass diperoleh bahwa $b_{1}=0,624$. Hal ini berarti besarnya elastisitas penggunaan luas lahan terhadap produksi padi sawah organik adalah sebesar $0,624 \%$. Dengan kata lain apabila terjadi penambahan dalam luas lahan yang diusahakan sebesar $10 \%$ maka akan terjadi perubahan kenaikan dalam produksi sebesar $6,24 \%$. Hasil pengujian secara parsial luas lahan terhadap produksi diperoleh $t_{\text {hit }}$ sebesar 7,288 lebih besar dari $t_{\text {Tabel }}$ yaitu 1,684 pada taraf $95 \%$, maka keputusannya tolak $H_{0}$ terima $\mathrm{H}_{1}$ yang berarti penambahan luas lahan berpengaruh sangat nyata terhadap peningkatan produksi.

Dari hasil pendugaan regresi berdasarkan fungsi produksi Cobb Douglass diperoleh bahwa $\mathrm{b}_{1}=0,293$ dimana nilai Ep berada pada daerah II yaitu $0 \leq \mathrm{Ep} \leq 1$, yang artinya bila dilakukan penambahan faktor produksi benih sebesar $10 \%$ akan mengakibatkan penambahan hasil produksi sebesar 2,93\%. Dari hasil penelitian di daerah penelitian jumlah produksi yang diperoleh di beberapa petani dengan penggunaan benih yang berbeda masih kurang bervariasi. Namun secara keseluruhan dapat dikatakan bahwa ada kecenderungan dengan pertambahan benih maka akan meningkatkan produksi padi sawah organik. Faktor benih akan mempengaruhi hasil produksi dimana benih bermutu adalah syarat utamanya. Ciri benih bermutu adalah jenisnya murni, bernas, kering, sehat, dan bebas dari campuran biji rerumputan yang tidak dikehendaki (Andoko, 2008). Benih yang bermutu memiliki daya kecambah sekitar 90 persen. Benih yang bermutu dapat menghasilkan produksi yang baik serta diikuti perlakuan agronomi yang baik dan input teknologi yang berimbang,sebaliknya bila bemih yang digunakan tidak berkualitas baik maka produksinya banyak tidak menjanjikan atau tidak lebih baik dari penggunaan benih bermutu. Penggunaan benih berkualitas diharapkan mampu mengurangi berbagai faktor resiko kegagalan panen.

Penggunaan faktor produksi tenaga kerja didaerah penelitian diperoleh hasil koefisien regresi sebesar 0,078 dimana nilai Ep berada pada daerah II yaitu $0 \leq \mathrm{Ep} \leq 1$, yang artinya bila dilakukan penambahan faktor produksi tenaga kerja sebesar $10 \%$ akan mengakibatkan penambahan hasil produksi sebesar $0,78 \%$. Hal ini sesuai dengan teori menurut Suratiyah (2011) yang menyatakan bahwa dipandang dari sudut efisiensi, semakin efisien tenaga kerja yang digunakan maka semakin efisien biaya yang dikeluarkan.

Dari hasil penelitian, tidak berpengaruhnya pupuk organik terhadap produksi disebabkan oleh pemberian pupuk organik pada jumlah tertentu tidak selalu memberikan efek terhadap produksi secara signifikan hal ini disebabkan karena keadaan tanah yang sudah subur. Begitu pula pada penggunaan obat-obatan dimana keadaan padi organik menggunakan varietas benih lokal yang 
mana padi organik rentan terhadap penyakit. Hal inilah yang menyebabkan faktor produksi tersebut diatas pada tingkat kepercayaan 95 persen tidak berpengaruh nyata terhadap produksi padi, atau nilai elastisitas produksi faktor produksi tersebut sama dengan nol. Hal ini menunjukkan penggunaan faktor produksi berupa pupuk organik dan obat-obatan mencapai tahap titik jenuh, dimana pada tahap ini tidak terjadi peningkatan ataupun penurunan produksi.

\section{Analisis Efisiensi Ekonomi Penggunaan Faktor Produksi dalam Usahatani Padi Sawah Organik Analisis Efisiensi Ekonomi}

Berdasarkan hasil penelitian yang telah dilakukan diperoleh hasil perhitungan efisiensi ekonomis tiap faktor produksi sebagai berikut :

Tabel 7 : Hasil Perhitungan Efisiensi Ekonomi Penggunaan Faktor Produksi di Daerah Penelitian Musim Tanam 2013

\begin{tabular}{lcrrr}
\hline \multicolumn{1}{c}{ Faktor Produksi } & $\begin{array}{c}\text { Koef. } \\
\text { Regresi }\end{array}$ & \multicolumn{1}{c}{ NPMxi } & \multicolumn{1}{c}{ Hxi } & NPMxi/Hxi \\
& & & 1.000 .000 & 18,7 \\
\hline Lahan (X1) & 0,624 & 18.699 .560 & 6.000 & 61,00 \\
Benih (X2) & 0,293 & 366.045 & 75.000 & 0,31 \\
Tenaga Kerja (X5) & 0,078 & $23.668,8$ & & \\
\hline
\end{tabular}

Dari Tabel 7 diatas dapat diketahui bahwa nilai perhtungan NPM $M_{x 1} / H_{x 1}>1$ yaitu 18,7 artinya penggunaan lahan di daerah penelitian belum efisien secara ekonomi. Hal ini berarti penggunaan faktor produksi lahan pada usahatani padi sawah organik di daerah penelitian dapat ditambah guna mendapatkan produksi optimal dan keuntungan maksimum. Rata-rata penggunaan lahan di daerah penelitian adalah sebesar $0,78 \mathrm{Ha}$ per petani. penggunaan luas lahan yang lebih besar maka akan menambah produksi usahatani padi sawah organik (Andoko, 2002)

Dari tabel diatas diketahui bahwa nilai NPM $\mathrm{x}_{\mathrm{x} 2} / \mathrm{H}_{\mathrm{x} 2}>1$ yaitu 61,00 artinya penggunaan benih di daerah penelitian belum efisien. Hal ini berarti penggunaan benih pada usahatani padi sawah organik di daerah peneltian dapat ditambah pemakaiannya guna untuk memperoleh hasil produksi yang optimal dan keuntungan yang optimal. Di daerah penelitian penggunaan benih rata-rata sebanyak 23,98 $\mathrm{kg}$ per petani atau setara dengan 18,71 per hektar, bila dibandingkan dengan rekomendasi penggunaan benih menurut Andoko (2002), rata-rata penggunaan benih untuk usahatani padi sawah organik berkisar $30 \mathrm{Kg} / \mathrm{Ha}$, maka penggunaan benih di daerah penelitian untuk usahatani padi sawah organik masih tergolong rendah.

Dari tabel diatas diketahui bahwa perhitungan analisis efisiensi penggunaan tenaga kerja dapat dilihat bahwa nilai perbandingan $\mathrm{NPM}_{\mathrm{x} 5} / \mathrm{H}_{\mathrm{x} 5}<1$ adalah 0,31 . Berarti dengan demikian penggunaan faktor produksi tenaga kerja di daerah penelitian tidak efisien. Tingkat penggunaan tenaga kerja yang tidak efisien ini dapat ditanggulangi dengan mengurangi jumlah tenaga kerja dengan pengurangan penggunaan tenaga kerja memungkinkan untuk meningkatkan tingkat produksi yang optimal. Hal ini tidak sejalan dengan rekomendasi penggunaan tenaga kerja normatif oleh pemerintah yaitu, $85 \mathrm{HOK} /$ ha sedangkan di daerah penelitian penggunaan tenaga kerja ratarata sebanyak 101, 83 HOK per petani atau setara dengan 79,43 HOK per hektar, bila dibandingkan dengan penggunaan tenaga kerja untuk usahatani padi sawah organik masih dibawah anjuran pemerintah, dan perlu penambahan.

\section{Penerimaan dan Analisis Revenue Cost Rasio}

Penerimaan usahatani adalah nilai produksi usahatani yang dihitung dalam uang. Penerimaan dapat diperoleh dengan mengalihkan produksi padi sawah organik dengan harga. Dalam 
penelitian ini harga gabah kering padi berkisar Rp.5.000, sehingga didapat penerimaan seluruh sampel sebesar Rp.1.051.850.000,- dan penerimaan rata-rata petani adalah Rp. 23.374.444-. Adapun besarnya penerimaan petani dari usahatani padi sawah organik dapat dilihat Tabel 8 berikut :

Tabel 8. Penerimaan dan R C Rasio Usahatani Padi Sawah Organik Di Daerah Penelitian Pada Musim Tanam Tahun 2014.

\begin{tabular}{llcc}
\hline Uraian & Penerimaan (Rp) & Total Biaya & R C Rasio \\
\hline Per Petani & 23.374 .450 & Rp. 6.682.622 & 3,5 \\
Per Hektar & 29.839 .700 & Rp. 385.535.897 & 0,07 \\
\hline
\end{tabular}

Hasil Olahan Data Primer 2015

* Harga Gabah $=0,59 \times$ Rp. $8500=$ Rp. 5.000

Konversi $1 \mathrm{Kg} \mathrm{GKG}=0,58 \mathrm{Kg}$ Beras

Efisiensi usaha dapat dihitung dengan menggunakan $\mathrm{R} C$ rasio, yaitu perbandingan antara penerimaan dan biaya yang dikeluarkan. Nilai $\mathrm{R} C$ rasio usahatani padi sawah organik diperoleh dari perbandingan antara rata-rata total penerimaan (Rp. 23.374.444) dengan rata-rata total biaya (Rp.6.682.622) yaitu sebesar 3,5 $>1$. Besar efisiensi usaha padi organik di Desa Pasar Terusan adalah sebesar 3,5. Angka ini menunjukkan bahwa usahatani padi organik di Desa Pasar Terusan Kecamatan Muara Bulian yang telah dijalankan telah efisien yang ditunjukkan dengan besarnya nilai $\mathrm{R} C$ rasio yang lebih dari satu $(R / C>1)$.

R C rasio menunjukkan pendapatan kotor yang diterima untuk setiap rupiah yang dikeluarkan untuk memproduksi. Nilai $R$ C rasio 3,5 berarti bahwa setiap $R p$. 1,00 biaya yang dikeluarkan dalam suatu awal kegiatan usaha memberikan penerimaan sebesar 3,5 kali dari biaya yang telah dikeluarkan. Semakin besar $\mathrm{R} C$ rasio maka akan semakin besar pula peneriman yang akan diperoleh. Nilai R C rasio dalam usahatani padi organik di Desa Pasar Terusan Kecamatan Muara Bulian telah efisien. Hal ini disebabkan penggunaan faktor produksi secara efisien, contohnya adalah penggunaan benih secara tepat dan tidak berlebihan.

\section{Biaya Produksi}

Biaya produksi usahatani padi sawah organik adalah biaya pembelian sarana produksi (benih, pupuk, obat-obatan dan upah tenaga kerja). Berikut biaya produksi usahatani padi sawah organik pada musim tanam tahun 2014 dapat dilihat pada Tabel 25 :

Tabel 9. Biaya Produksi Usahatani Padi Sawah Organik Di Daerah Penelitian Pada Musim Tanam Tahun 2014.

\begin{tabular}{clcc}
\hline No & \multicolumn{1}{c}{ Biaya Produksi } & Rata-rata (Rp) & Persentase (\%) \\
\hline $\mathbf{1}$ & Benih & 112.267 & 1,68 \\
$\mathbf{2}$ & Pupuk & 268.889 & 4,02 \\
$\mathbf{3}$ & Obat-obatan & 344.300 & 5,15 \\
$\mathbf{4}$ & Tenaga Kerja & 5.957 .167 & 89,15 \\
\hline \multicolumn{2}{r}{ Total Biaya } & $\mathbf{6 . 6 8 2 . 6 2 3}$ & $\mathbf{1 0 0}$ \\
\hline
\end{tabular}

Dari Tabel 25 terlihat bahwa biaya produksi rata-rata paling besar adalah biaya tenaga kerja yaitu sebesar Rp. 5.957.167,- dengan persentase 89,15\%, kemudian biaya obat-obatan sebesar Rp. 344.300 ,- dengan persentase 5,15\% dan biaya pupuk sebesar Rp. 268.889 dengan persentase 4,02 $\%$ dan biaya terkecil yang dikeluarkan petani adalah biaya benih yang mana hanya Rp. 112.267 dengan persentase hanya $1,68 \%$. 


\section{KESIMPULAN.}

\section{Kesimpulan}

Berdasarkan diperoleh kesimpulan sebagai berikut (1) Pertanian yang diterapkan di Desa Pasar Terusan lebih mendekati sistem pertanian alamiah hal itu mengacu pada salah satu pengertian mengenai pertanian organik. Petani di Desa Pasar Terusan sudah menggunakan pupuk organik seperti yang digunakan dalam pertanian organik pada umumnya, yaitu pupuk kandang sehingga menjadi pupuk organik atau petani mendapatkan bantuan dari pemerintah yaitu pupuk organik petrorganik. (2) Secara bersama-sama penggunaan faktor produksi luas lahan, benih, pupuk dan tenaga kerja mempengaruhi produksi padi sawah organik dan berpengaruh nyata terhadap peningkatan produksi padi sawah organik dan secara parsial obat-obatan tidak berpengaruh nyata terhadap produksi. (3) Dari hasil analisis menunjukkan bahwa koefisien determinasi $\left(R^{2}\right)$ sebesar 0,996. Hal ini berarti 99,6\% variasi produksi dapat dijelaskan secara bersama-sama oleh faktor produksi lahan, benih, pupuk organik, obat-obatan dan tenaga kerja secara parsial yang berpengaruh nyata terhadap produksi lahan, benih, pupuk, dan tenaga kerja sedangkan obat-obatan tidak berpengaruh nyata. Faktor produksi yang memiliki indeks efisiensi ekonomi > 1 adalah lahan, benih, artinya faktor produksi tersebut perlu ditambah sedangkan indeks efisiensi ekonomi $<1$ yaitu tenaga kerja artinya faktor produksi tersebut perlu dikurangi.

\section{UCAPAN TERIMAKASIH}

Ucapan terima kasih disampaikan kepada Dekan Fakukltas Pertanian Universitas Jambi dan Ketua Jurusan Agribisnis Fakultas Pertanian Universitas Jambi yang telah memfasilitasi pelaksanaan penelitian ini, ucapan terima kasih juga penulis sampaikan kepada Penyuluh Pertanian Lapangan Desa Pasar Terusan, Kepala Desa Pasar Terusan, BP3K Kecamatan Muara Buliian dan warga yang telah membantu pelaksanaan penelitian di lapangan.

\section{DAFTAR PUSTAKA}

Andoko, Agus. 2008. Budidaya Padi Organik. Penebar Swadaya. Jakarta Departemen Pertanian. 2007. Kebijakan Pembangunan Pertanian. Departemen Pertanian. Jakarta. Gujarati, Damodar. 2003. Ekonometrika Dasar. Erlangga. Jakarta.

Singarimbun, Masri \& Sofian Effendi, Metode Penelitian Survai, Penerbit Pustaka LP3ES Indonesia, Jakarta, 2006

Siregar, Hermanto. 2010. Ekonomi Empiris Pangan; Suatu Prespektif Jangka Pendek Makalah Disampaikan Pada Seminar Nasional Fakultas Pertanian USU, Medan.

Soekartawi. 1988. Prinsip Dasar Komunikasi Pertanian. UI Press. Jakarta.

Soekartawi.. 1994. Teori Ekonomi Produksi Dengan Pokok Bahasan Analisis Fungsi Cobb-Douglas. PT. Raja Grafindo Persada. Jakarta. 